\title{
Creating transnational, intercultural arts' interactions: African diasporic dialogues
}

\author{
Alix Pierre \\ Spelman College \\ alixpierre2@yahoo.com
}

\begin{abstract}
Painted with broad as well as, highly nuanced brush strokes, this is a comprehensive essay. Initially, it traces and later weaves within the larger discussion, the influences of Marcus Garvey's philosophy and his lasting contributions to Africans in the diaspora. As importantly, the essay highlights the exceptional works of two Jamaican-born artists who reside in the USA. Thirdly, the essay explores some of the Miami-based Diaspora Vibe Cultural Arts Incubator's, (DVCAI's) intercultural exchanges, in which artists challenge dominant Western perspectives. Fourthly, the essay summarizes key aspects of DVCAI's international cultural exchange in Jamaica. The recent, transcultural arts' exchanges exemplify, reciprocal dialogues between the DVCAI's representatives and the Jamaican arts community, specifically, with artists who adopt a Freirean pedagogy and focus on significant social justice issues in a postcolonial country.
\end{abstract}

Keywords: African Diaspora Arts, African Diaspora Studies, Transnationalism, Caribbean Visual Arts, International Cultural Exchanges

\section{Introduction}

Marcus Garvey's speech in Harlem, New York, disrupted deliberately, conventional thinking when he stated that:

The world today is indebted to us for the benefits of civilization. They stole our arts and sciences from Africa. Then why should we be ashamed of ourselves? Their modern improvements are but duplicates of a grander civilization that we reflected thousands of years ago, without the advantage of what is buried and still hidden, to be resurrected and reintroduced by the intelligence of our generation and our posterity. (Garvey, 1924, p. 5)

In his speech, the Jamaican, founder of Garveyism, an international social change movement, issued a clarion call. Following suit with other Pan African intellectual precursors such as, Edward Wilmot Blyden, Alexander Crummell, Henry McNeil Turner, Henry Sylvester Williams, and his contemporaries including, W. E. B. DuBois, Marcus Garvey challenged the West's widely accepted, negative perspectives of the African continent and its people. The highly esteemed German philosopher, Georg Hegel, for example theorized and espoused notions of the continent's alleged inferiority. Hegel framed such a discourse in his lectures and writing. In 1830, he declared that Africa had no history and had made no contribution to the world. At present, however, new scholarship on Garveyism is emerging in the United States. Researchers are reevaluating and contextualizing the major African Diasporic movement whose significance had been overlooked. Researchers specifically, Mary G. Rolinson (2007), Asia Leeds (2010), Claudrena Harold (2007), Adam Ewing (2014), Taylor Coleman (2017) and Trent Vinson (2012)

Cultural and Pedagogical Inquiry, Fall 2019, 11(3), pp. 36-51

ISSN 1916-3460 @ 2019 University of Alberta

http://ejournals.library.ualberta.ca/index.php/cpi/index 
are bringing to the forefront Marcus Garvey's significance in the transnational approach to African Diaspora studies.

\section{Nari Ward and Ebony Patterson's contribution to the US visual arts}

From music to literature, Jamaica's contribution to the arts has long been established. Currently, two contemporary Jamaican-born visual artists, Nari Ward and Ebony Patterson, have a strong presence on the North American art scene. Ward's works explore issues of race, immigration, poverty, consumer culture, and Caribbean identity through assemblages of found objects. In 2017, Nari Ward was awarded the Vilcek Prize in Fine Arts in recognition of his outstanding contribution, as an immigrant, to the arts and sciences. The Vilcek Foundation, which bestowed the US $\$ 100,000$ prize, referenced one of his major works, Naturalization Drawing Table (2004). The interactive installation portrays a large desk created from Plexiglas bodega barricades decorated with applications to the US Immigration and Naturalization Service. In referring to Ward's work, Sarah Cascone of Arnet (the art market website), states that "The work, now especially timely, given President Donald Trump's recent executive order, invites viewers to participate in the bureaucratic process of gaining citizenship" (Cascone, 2017, p. 4).

In 2018, a graduate of the Edna Manley College of the Visual and Performing Arts, Ebony Patterson's social justice art was acclaimed when she was granted the United States Artists Fellowship Award in Visual Arts, the Stone and the DeGuire Contemporary Art Award from the Sam Fox School of Design and Visual Arts. In 2017, she received the Louis ComfortTiffany Foundation Biennal Grant. This fall, the Perez Art Museum will launch a major traveling exhibition of her work, accompanied by her first monographic catalogue. In discussing Patterson's work, Wayne Modest and Rivke Jaffe state:

Ebony Patterson, a young artist who moves between Jamaica and the US, is arguably the artist most concerned with rethinking the social through the lens of the ghetto. In her flamboyant, carefully constructed scenes, Patterson explores the complexity of lives in the ghetto. The main protagonists in her work are Jamaica's iconic gangster figures, known as the badman, the rudebwoy, and the don. Patterson's work offers a more textured, layered exploration of these infamous figures, whose life is generally reduced to more simplistic ideas about violence. In her scenes these young black men from the ghetto - so rarely portrayed in previous works of art - are powerful social actors, in charge of their own futures and helping to shape a new Jamaican aesthetic. (Modest \& Jaffe, 2014, p. 236)

Quite understandably, both Jamaican-born artists depict significant social, economic and political issues in their work.

\section{The Diaspora Vibe Cultural Arts Incubator (DVCAI)}

For the past 22 years, Miami-based Diaspora Vibe Culture Arts Incubator (DVCAI) has been promoting dialogues between artists of the global south through intercultural exchanges. Selected arts creators have travelled across the Caribbean Sea and Atlantic Ocean to participate in cultural exchanges, which Paul Gilroy suggests must be viewed as complex units of analysis in our discussion of the modern world and used to "produce an explicitly transnational and intercultural perspective" (Gilroy,1993, p. 15). The plasticians, for example, have debated 
Diasporan art and culture with their counterparts in Anglophone, Hispanophone, Dutch and Francophone Caribbean nations. Referencing Edouard Glissant, Kamau Brathwaite, Aimé Césaire, and Benitez Rojo, through workshops, roundtables, studio visits and exhibits, they have discussed what it means to be artists living and working in the global south of which Miami is a demographic extension.

Since 2009, DVCAI has been investigating the Jamaican aesthetic. This spring, we completed the last of three international cultural exchanges there. The 2018 conversation: "Voyaging Towards the Future: Living Sculpture III," was a follow up to the 2012: "Living Sculpture II" and the 2009: "Living Sculpture" themes. The title is a reference to the Jamaican, Caribbean Sculpture Park, which is the only open-air museum in the English-speaking Caribbean.

In this section of the essay, I explore the concept and practice of DVCAI's International Cultural Exchanges (ICE) as being, examples of diaspora in-the-making. Two scholars, Ruby Patterson and Robin Kelley (2000) state that diaspora or migration is an unfinished process. The process is constantly in the making at the intersections of race and gender, and moves across frontiers. According to Patterson and Kelley (2000, p. 37), this process operates along "legal, cultural, economic, imperial and social lines."

I suggest that Garvey's perspectives correlate with Kelley and Patterson's (2000) views on two levels. First, Marcus Garvey's quote at the beginning of this article, addresses significant issues of cultural appropriation, white supremacy and colonization that prevail in the West. An illustrative, case in point, is the recent appointment of a white American woman, as the chief curator of the Brooklyn Museum's African collection. The 'Decolonize this Place' movement, based in New York, sees this appointment as further proof of the lack of diversity of curatorial staff and executive leadership. (Presently, most American curators are middle-aged, white males). Despite New York's reputation as a racially and ethnically diverse city, at most art institutions, the number of people of color and African American board members are significantly low (Pogrebin, 2017). Further, a study conducted by The New York Times, discovered that the most prestigious organizations employ overwhelmingly, a white staff (Pogrebin, 2017). Ironically, arts organization practice low rates of minority hiring, yet at the same time, they are busy inviting and increasing minority membership. Furthermore, a survey conducted by New York's, Department of Cultural Affairs, revealed that in art and culture, the curator holds the white job, par excellence. At the lower ranks of the occupational hierarchy, the black workforce occupies jobs in maintenance and security. It is no surprise that the hiring practices in the art world, tend to mirror hiring in mainstream organizations.

Given the presence on the board of the Brooklyn Museum of a prominent real estate developer, whose company has been acquiring properties owned by black and brown residents at a fast pace and for inexpensive sums, the 'Decolonize this Place' movement views the recent appointment of the white woman curator as part of the larger gentrification process which is occurring at a steady rate, in many major US urban centers. In New York, the gentrification process, based on race and ethnicity, seeks to dispossess and displace minorities of prime real estate properties.

The second connection with Marcus Garvey's thinking refers to his life and career, which represent perfect examples of Patterson and Kelley's (2000) concept of diaspora in the making. 
Garvey's life and career symbolize international movement, migration, travel as well as the production of thought, culture, and political struggle. Garveyism (the social movement), was born from his lived experiences in Jamaica, his stays in: Central America (Costa Rica, Panama, Honduras, and Belize), England, the US and Europe. Garvey's interactions with blue-collar workers at home and abroad, as well as his readings and exchanges with Black thinkers all shaped his intellectual development and the tenets of the Universal Negro Improvement Association (UNIA) which he founded. In time, the UNIA developed hundreds of divisions throughout North and Central America, the Caribbean, Africa, Britain as well as Australia. The UNIA held international conventions attended by representatives from all over the world. The affiliated, newspaper, the Negro World, was published globally with sections in French and Spanish, in addition to English.

A sophisticated communication network buttressed the Garveyite strategies of international mass organizing. Adam Ewing, for example, states that Garveyism was "a sustained project of diasporic identity building" (Ewing, 2014, p. 7). Ewing emphasizes that, "The primary goal of the organization was to refocus their gaze on racial cooperation and progress" (p. 9). He suggests that the "effect of Garveyist organizing was to empower black communities to direct attention to their own need, to build upon their own traditions, to confront systems of power within the purview of their own discretion" (Ewing, 2014, p. 7).

The 2018, DVCAI cultural exchanges challenge 'systems of power'. For example, the most recent DVCAI international exchange in Jamaica was entitled: "Voyaging towards the Future: Living Sculpture III." The overarching questions were: What was the topic of the conversation? What was the voyage about? Where were we going? How were we going? Who was going? Through what prism did the radical eyes see? What did the artists hope to see and capture? To what end? The answers to the questions were at the intersection of three key spaces, namely: 1) exhibition and performing spaces, 2) spaces/places in art institutions of learning and training, and 3) spaces of creation.

In Jamaica, the Edna Manley College of the Visual and Performing Arts (EMCVPA) and the Sculpture Park in Kingston depicted two ends of the art continuum, with artists' studios and art galleries located at strategic places between them. The examples identified on the continuum, resonated with DVCAI's ICEs as illustrated in the main educational organizations', mission statements and visions. EMCVPA seeks for example, "To enrich the aesthetic sensibilities and promote the cultural diversity of the Caribbean through the highest quality education and training in the Visual and Performing Arts" (EMCVPA, 2018, p. 1). For its part, the Caribbean Sculpture Park aims to "facilitate the sensitization of the UTech [University of Techonology] community and the wider populace to the arts. As such, the Park is earmarked for activities which offer cultural, educational, social and spiritual enhancement to the University" (Utech, 2008-2016, p. 1).

The visions of both local entities intersect and are illustrated well, by artist, Christopher Gonzalez's career. One of the first EMCVPA graduates and later on, a lecturer at his Alma matter, Gonzales contributed "The Icon of togetherness" to the Park. In 1979, he moved to Atlanta to hold an artist-in-residence position at Spelman College where I teach. Like the Jamaican College of Art, the Caribbean Sculpture Park integrates Pan Africanism by offering works by artists from various Caribbean countries including: Cuba, Barbados, Grenada, and St. Lucia, and by artists as far afield internationally, as Kenya and Russia. Such inclusivity, 
correlates with Patterson and Kelley's (2000) suggestions that "shifting the discussion from an African-centered approach to questions of black consciousness to the globality of the diasporain-the-making allows for a rethinking of how we view Africa and the world, and opens up new avenues for writing a world history from below" (Patterson \& Kelley, 2000, p. 45).

DVCAI's mission statement echoes the quote, above. The collective's website reads, "Our artists break boundaries of traditional forms and work outside of institutionalized systems. They often must create new systems and infrastructures to sustain their practice." Similarly, the Jamaican participants in the 2018 DVCAI intercultural exchange pursue the same goal. Members of the two groups make art in and/or for public places that transform civic spaces. As importantly, the artists celebrate communities. The communities of men, women, and children whose very existence contests Western representation in the media and the arts which generally present a skewed representation of the others. A representation still informed for the most part, by traditional Western perspectives of discovery, conquest, colonization of the Americas, the slave trade and enslavement of Africans.

The narratives of the DVCAI plasticians and the works of the Jamaican artists participating in the ICE, are mostly centered on questions of heritage, kinship, and learning. They contest the denial and erasure of representations of black and brown people. They challenge the Western conventions of pictorial depictions of racialized minorities. Such dominant images tend to place non-white subjects and their cultures on the periphery (if at all), in the grand narrative.

For the most part, the works of the ICE artists integrate central socio-economic, urban and rural issues. In the case of Jamaica, the artists include images of garrisons and ghettos. Rather than the banking system of art education which holds that the instructor knows everything, and the students are empty vessels to be filled, the artists suggest a problem-posing approach to education and urban planning that is congruent with the Edna Manley (EMCVPA) and the Caribbean Sculpture Park's educational strategies. The UTech students and the larger population who interact with artwork in public spaces, throughout the island, are invited to think of their place in the world through active engagement with the artifacts. They are empowered to think critically, and to contribute their thoughts and responses to the exhibitions.

These community-led initiatives as well as the overall arching goal of DVCAI, signal a significant departure from the traditional Eurocentric art-for-art's-sake approach that conveys the idea that the chief or only aim of a work of art is the individual artist's (the creator's) selfexpression. In contrast, the artists discussed in this essay, ground their works in the community. They reveal a marked shift from the Western capitalist and individualistic mindset. The artists remind us that we are only as strong as our most important human connections. That in essence is the core belief of the African Ubuntu circle, the essence of being truly human. As Desmond Tutu aptly stated: "We think of ourselves far too frequently as just individuals, separated from one another, whereas you are connected and what you do affects the whole world... My humanity is caught up, inextricably bound up in what is yours" (Tutu, 2016, p. 10). 


\section{Conclusion}

During the 10-day exchange in Jamaica, we experienced the vibrancy and strength of the contemporary Jamaican art scene. We met with a cross section of representatives of the art world, including plasticians, museum directors, gallery owners, collectors, and art students. We visited museums, galleries, artist studios, and an art school. As we crisscrossed the island and navigated urban as well as rural settings, we were impressed with the strength of the art language, its pluralism concerning media, gender, and ethnicity. We agree with art historian, curator and essayist Petrine Archer statements regarding, the groundedness of contemporary Jamaican art. In a 2011 essay she declared,

But in the past decade events "on the ground" in Jamaica have made a number of our contemporary artists more abruptly aware of the present. The art of this new millennium appears to be shifting in focus and style again in ways that reflect their acute sense of social issues and activism. Artists such as Ebony G. Patterson, Michael Elliot, Gerard Hanson, and Peter Rickards are engaging with concerns such as violence, homophobia and social dislocation that have been a feature of Jamaica's recent past. This generation of artists compete with the more glaring aspects of Jamaica's popular culture related to dance hall, ghetto fabulous fashions, and the aesthetics of bling funerals for a stake in the nation's visual memory. They are taking their art to the streets to meet that culture on its own terms with a visual language that now has the privilege of an art historical past, even as it moves forward. (Archer, 2011, p. 6)

Contemporary artists such as Philip Supersad, Katrina Coombs, Samere Tansley, Heather Sutherland, David, Leonia, Andranique, Munchi, Raymond Watson, Mazola Mwashigadi, Petrona Morrison, Deborah Anziger, Claudette Lopez-Lewis, Donnette Zacca, Stefan Clarke, Paula Daley, Norma Harrack, Laura Facey, Judith Salmon can be added to Petrine Archer's list of four artists, in her quote above. During the most recent DVCAI intercultural conversations in Jamaica, the ongoing dialogues with DVCAI's participants, Rosa Naday Garmendia, Anna Carolyn Meier, Moises Aragon, Jacqueline Gopie, Onajide Shabaka, Asser Saint-Val, Izia Lindsay and the documenting photographer, Roy Anthony Wallace were rich and fruitful. Carol Campbell, master jeweler who teaches at Edna Manley and for years managed a premiere art gallery in Jamaica, was instrumental in facilitating such a meaningful collaboration.

DVCAI's Founder and President, Rosie Gordon-Wallace, is a visionary and advocate of diasporan art and culture. Through the International Cultural Exchanges, DVCAI has designed a distinct and successful model of intrablack and brown dialogues. The 2018, "Voyaging towards the Future: Living Sculpture III", intercultural dialogues, as discussed, have played an integral role. Michael Elliot's residency in Miami this past summer, as well as the bestowing of the 2018 Ellie Schneiderman Award to Rosa Naday Garmendia, Juana Valdes and Onajide Shabaka further, grounds DVCAI's work in local and transnational contexts. In the concluding section of this essay, samples of social justice artwork by: Rosa Naday Garmendia, Michael Elliot, and Onajide Shabaka, indicate explicitly, the artists abilities to engage, and disrupt mainstream depictions of racialized minorities. 


\section{Photograph 1:}

\section{“Liberty Flags” -- Walter Scott Series}

By Rosa Naday Garmendia

Description: Liberty Flags emerged as an extension of and runs parallel to Rituals of Commemoration, a work of art that serves as a space-holder, a memory legacy, which will ensure that the names of victims of police brutality are not forgotten. The genesis of these projects is the killing of Michael Brown in August of 2014, in Ferguson, Missouri. The Liberty Series is made up of ten flags that serve as markers in support of symbolically and physically memorializing and commemorating these lives. Giving the lives lost dignity and respect by creating a physical space of remembrance and a symbolic acknowledgment of a difficult present. The design includes images and text found through research about the facts of each killing. Each mixedmedia paper piece is scanned and printed into 3'x5' nylon flags. Naday Garmendia's fundamental unwavering belief in justice fuels the desire to use these markers meaningfully, marking lives lost. She sees it as an act of disruption that will provoke conversation, hold memory and interrogate viewers' own unconscious biases.

Mixed media on paper.

34 inches high by 22 inches wide.

Reproduced with permission from Rosa Naday Garmendia, November 28, 2018. 


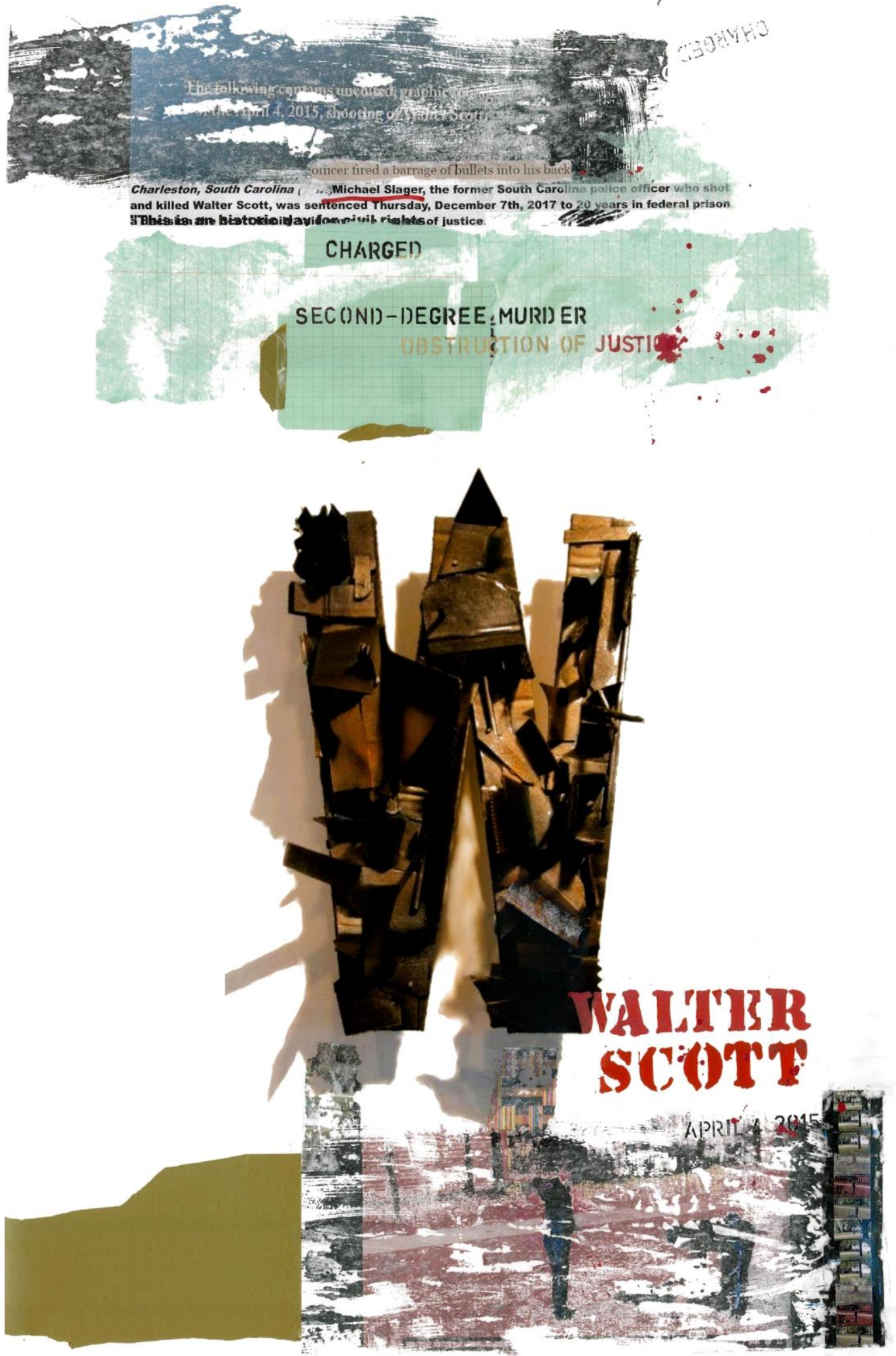

Cultural and Pedagogical Inquiry, Fall 2019, 11(3), pp. 36-51

ISSN 1916-3460 @ 2019 University of Alberta

http://ejournals.library.ualberta.ca/index.php/cpi/index 


\section{Photograph 2:}

\section{“May Day, Man Overboard"}

By Michael Elliot

Description: Elliot had always been aware of the history of West Indians migrating to Great Britain and the social problems which developed there. However, the recent Windrush scandal opened his eyes to the magnitude of the problems. In the summer of 2018, he started cultivating ideas and creating pieces based on the Windrush saga. "May Day and the Man Overboard" is perhaps the piece in the series that represents an almost literal interpretation of the typical Windrush passenger as he sits well dressed on a sofa at the bottom of the ocean or in the depths of the sullied tea. In this case, Elliot has represented the male passenger, symbolically, as a living, breathing tea bag that is being drained, as he thinks that he is on the way to what has been called 'the promised land' in London. The piece signifies the broken hopes of the black man who has worked and even fought valiantly, in the two World Wars, for the Empire of Britain and the 'motherland'.

Acrylic on canvas.

39.5 inches by 27.5 inches.

Reproduced with permission from Michael Elliot, December 1, 2018. 


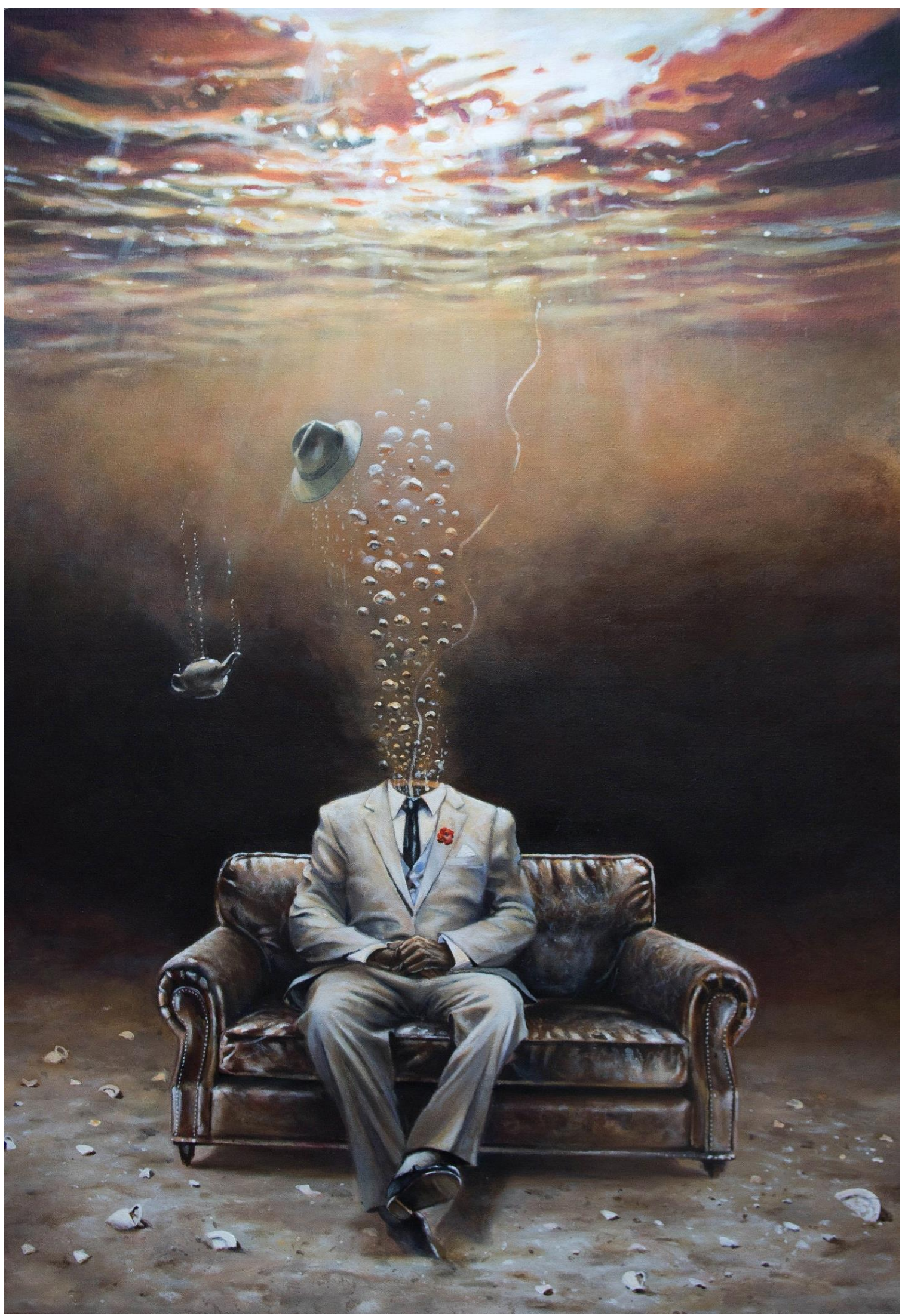

Cultural and Pedagogical Inquiry, Fall 2019, 11(3), pp. 36-51

ISSN 1916-3460 @ 2019 University of Alberta

http://ejournals.library.ualberta.ca/index.php/cpi/index 


\section{Photograph 3:}

\section{"The Snook's Demise came at the End"}

By Onajide Shabaka

Description: Since 1989, Shabaka's art practice has focused on ethnobotany, geology, and archeology. Happening upon the recent discovery of ancestral rice crops in Suriname that originated in the Côte d'Ivoire and was brought to the Americas in the hair of African enslaved women was a revelation for Onajide Shabaka. Researching these ancestral seeds in Suriname was richly rewarding. Furthermore, researching the fauna and flora, have expanded the breath of Shabaka's art practice through discoveries of plant, seed, insect, and paths of colonial migration. Mixed media collage on paper.

9 inches by 12 inches $/ 30.5 \mathrm{~cm}$ by $22.9 \mathrm{~cm}$.

Reproduced with permission from Onajide Shabaka, November 29, 2018. 


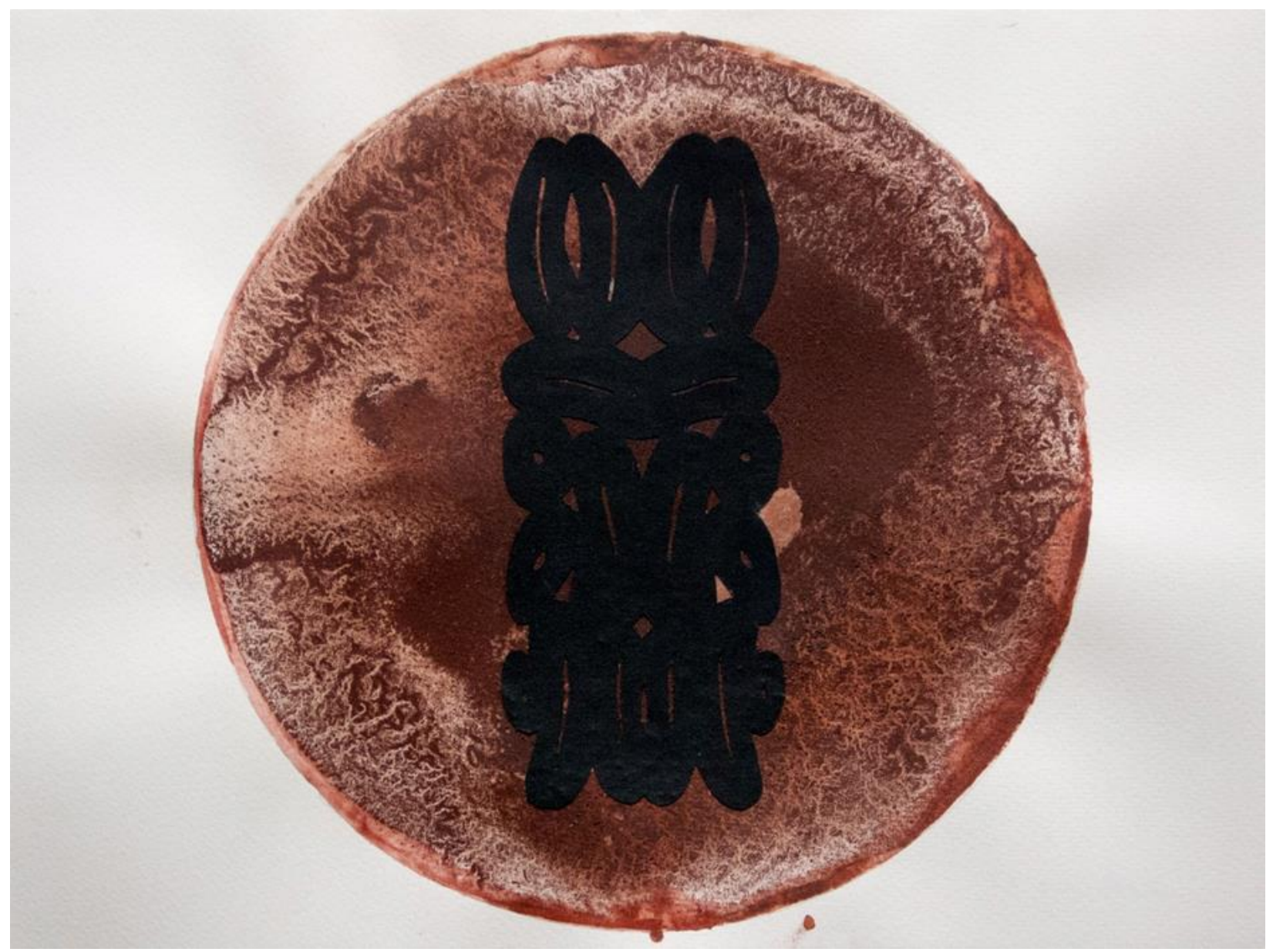

Cultural and Pedagogical Inquiry, Fall 2019, 11(3), pp. 36-51

ISSN 1916-3460 @ 2019 University of Alberta

http://ejournals.library.ualberta.ca/index.php/cpi/index 


\section{Photograph 4:}

\section{“The Harpy Eagle's Claw"}

By Onajide Shabaka

Description: Since 1989, Shabaka's art practice has focused on ethnobotany, geology, and archeology. Happening upon the recent discovery of ancestral rice crops in Suriname that originated in Côte d'Ivoire and brought to the Americas in the hair of African enslaved women was a revelation. Researching: (i) these ancestral seeds in Suriname was richly rewarding; (ii) both fauna and flora have expanded the breath of Shabaka's art practice through discoveries of plant, seed, insect, and paths of colonial migration.

Mixed media collage on paper.

9 inches by 12 inches $/ 30.5 \mathrm{~cm}$ by $22.9 \mathrm{~cm}$.

Reproduced with permission from Onajide Shabaka, December 1, 2018. 


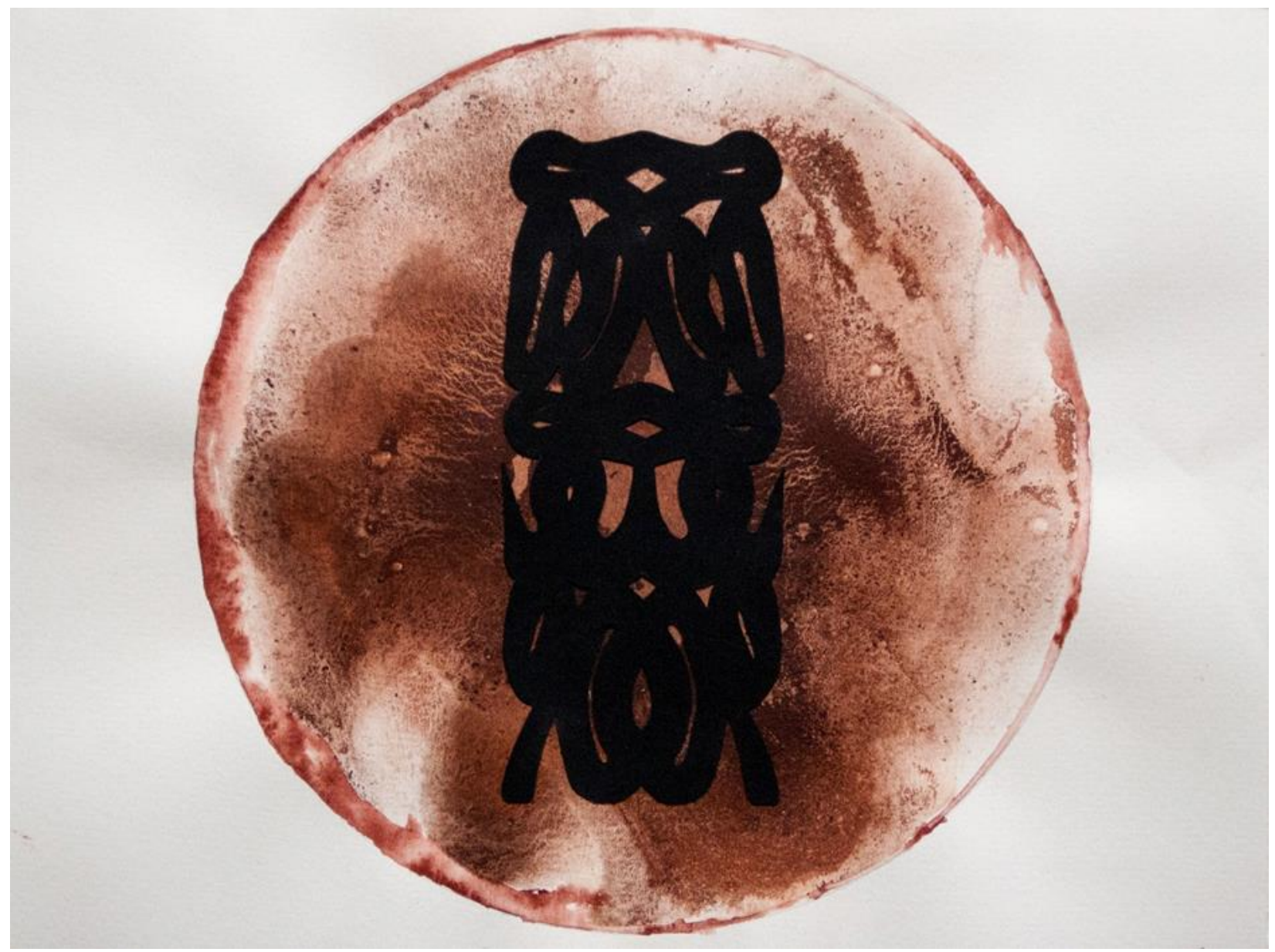

Cultural and Pedagogical Inquiry, Fall 2019, 11(3), pp. 36-51

ISSN 1916-3460 @ 2019 University of Alberta

http://ejournals.library.ualberta.ca/index.php/cpi/index 


\section{Works Cited}

Archer, P. (2011, May 18). “Jamaican art: Looking back moving forward”. Contemporary Jamaican Art: A Jamaican Presence in the About Change Exhibition.

Benitez-Rojo, A. (1997). The repeating island: The Caribbean and the postmodern perspective. Durham: Duke University Press.

Blyden, E. W. (1862). "The call of providence to the descendants of Africa in America”. In Liberia's offering: Being addresses, seminars, etc. New York: John A. Gray.

Blyden, E. W. (1884). Christianity, Islam and the Negro Race. London: W. B. Whittingham and Co.

Blyden, E. W. (1905). West Africa before Europe, and other addresses delivered in England in 1901 and 1903. London: C. M. Phillips.

Blyden, E. W. (1908). African life and custom. London: C. M. Phillips.

Brathwaite, K. (1967). Rights of Passage. Oxford: Oxford University Press.

Brathwaite, K. (1968). Masks. Oxford: Oxford University Press.

Brathwaite, K. (1969). Islands. Oxford: Oxford University Press.

Brathwaite, K. (1973). The Arrivants. Oxford: Oxford University Press.

Brathwaite, K. (1992). Middle Passages. Oxford: Oxford University Press.

Cascone, S. (2017, February). "Nari Ward receives Vilcek Prize for Immigrant Artists, with $\$ 100,000$ Cash Award”. news.artnet.com/art-word/nari-ward/100000-vicek-prize-immigrant-artist-842714

Césaire, A. (1972, 2000). Discourse on colonialism. New York: Monthly Review Press.

Coleman, T. (2017). Garveyism, the united Negro improvement association, and the construction of Black identity in early $20^{\text {th }}$ Century Cuba. ProQuest Limited.

Crummell, A. (2012). The future of Africa: Being addresses, sermons, delivered in the Republic of Liberia. London: Forgotten Books.

Dosset, K. (2008). Bridging race divides. Gainesville, University Press of Florida.

DuBois, W. E. B. (1903). The Souls of Black Folk. Chicago: A. C. McClurg and Co.

Ewing, A. (2014). The age of Garvey: How a Jamaican activist created a mass movement and changed global Black politics. Princeton: Princeton University Press.

Freire, P. (1996). Pedagogy of the oppressed. London: Penguin Education.

Garvey, M. (author), \& Hill, R. (2005). The Marcus Garvey and Universal Negro Improvement Association papers, Volume 2. Berkeley: The University of California Press.

Cultural and Pedagogical Inquiry, Fall 2019, 11(3), pp. 36-51

ISSN 1916-3460 @ 2019 University of Alberta

http://ejournals.library.ualberta.ca/index.php/cpi/index 
Gilroy, P. (1993). The Black Atlantic: Modernity and double consciousness. Cambridge: Harvard University Press.

Glissant, E. (1999). Poetic of relation. Anne Arbor: University of Michigan Press.

Glissant, E. (1999). Caribbean discourse. Charlottesville: University of Virginia Press.

Harold, C. (2007). The Rise and fall of the Garvey movement in the urban south, 1918-1942. New York: Routledge.

Hegel, G. (2010). The philosophy of history. Whitefish: Kessinger Publishing.

King, S. (2002). Reggae, Rastafari and the rhetoric of social control. Jackson: University Press of Mississippi.

Leeds, A. (2010). Representation of race, entanglement of power: Whiteness, garveyism, and redemptive geographies in Costa Rica, 1921-1950. Dissertation, University of California, Berkeley, ProQuest Dissertation Publishing. 3449004

McNeal Turner, H. (2010). African letters. Scotts Valley: CreateSpace Independent Publishing Platform.

Patterson, T. R., \& Kelley, D. G. (2002). Unfinished migration: Reflections on the African diaspora and the making of the modern world. African Studies Review, 43(1), 11-45.

Pogrebin, R. (2017, Aug 22). It's a Diverse City, but Most Big Museum Boards Are Strikingly White. New York Times.

Rolinson, Mary, G. (2007). Grassroots Garveyism: The Universal Negro Improvement Association in the South, 1920-1927. Chapel Hill: The University of North Carolina Press.

Vinson, T. R. (2012). The Americans are coming: Dreams of African American liberation in segregationist South Africa. Athens: Ohio University Press.

Walcott, D. (1999). What the twilight says. New York: Farrar, Straus and Giroux.

Wayne, M., \& Jaffe, R. (2014). New roots: Jamaican ontologies of blackness from Africa to the Ghetto. African Diaspora Studies, 7(2), 234-259.

Cultural and Pedagogical Inquiry, Fall 2019, 11(3), pp. 36-51

ISSN 1916-3460 @ 2019 University of Alberta

http://ejournals.library.ualberta.ca/index.php/cpi/index 